Swarthmore College

Works

\title{
Sacred-Land Theology: Green Spirit, Deconstruction, And The Question Of Idolatry In Contemporary Earthen Christianity
}

Mark I. Wallace

Swarthmore College, mwallac1@swarthmore.edu

Follow this and additional works at: https://works.swarthmore.edu/fac-religion

Part of the Religion Commons

\section{Recommended Citation}

Mark I. Wallace. (2007). "Sacred-Land Theology: Green Spirit, Deconstruction, And The Question Of Idolatry In Contemporary Earthen Christianity". Ecospirit: Religion, Philosophy, And The Earth. 291-314. DOI: $10.5422 /$ fso/9780823227457.003.0015

https://works.swarthmore.edu/fac-religion/82

This work is brought to you for free by Swarthmore College Libraries' Works. It has been accepted for inclusion in Religion Faculty Works by an authorized administrator of Works. For more information, please contact myworks@swarthmore.edu. 


\section{* Sacred-Land Theology: Green Spirit, Deconstruction, and the Question of Idolatry in Contemporary Earthen}

\section{Christianity}

MARK I. WALLACE

I enter a swamp as a sacred place—a sanctum sanctorum.

- henry david thoreau, "Walking"

This pneumatological materiality, far from effecting a spiritual disembodiment, a flight from the earth, suggests in its very birdiness a dynamism of embodiment: lines of flight within the world.

- Catherine keller, Face of the Deep

Christianity often acts like a "discarnate" religion - that is, a religion that sees no relationship between the spiritual and the physical orders of being. Historically, it has devalued the flesh and the world as inferior to the concerns of the soul. In the history of the church, the earth was considered fallen and depraved because of Adam's original sin in the Garden of Eden; many early theologians rejected marriage as giving in to sexual pleasure; and greatly revered saints and martyrs starved their bodies and beat themselves with sticks and whips in order to drive away earthly temptations. Pseudo-Titus, for example, an extracanonical exhortation to asceticism from late antiquity, urges Christians to cleanse themselves of worldly pollution by overcoming fleshly temptations: "Blessed are those who have not polluted their flesh by craving for this world, but are dead to the world that they may live for God!"' Christianity has been conflicted about, and at times at war with, the genuine human need to 
reconcile the passions of worldly, physical existence with aspirations for spiritual transformation.

In fact, however, Christianity is not a discarnate religion. On the contrary, beginning with its earliest history, Christianity offers its practitioners a profound vision of God's fleshly identity through its ancient teaching that God at one time embodied Godself in Jesus-God became incarnate. Long ago God poured out Godself into the mortal body of one human individual, Jesus. But that is not all. Christians also believe that since the dawn of creation, throughout world history and into the present, God in and through the Spirit has been persistently infusing the natural world with divine presence. The Spirit is the medium, the agent, or, in terms more felicitous for a recovery of the Bible's earthcenteredness, the life-form through which God's power and love fill the world and all of its inhabitants. Through green Christian optics, we see that the gift of the Spirit to the world since time immemorial—a gift that is alongside and inclusive of Jesus' death and resurrection-signals the beginning and continuation of God's incarnational presence. As once God became earthly at the beginning of creation, and as once God became human in the body of Jesus, so now God continually enfleshes Godself through the Spirit in the embodied reality of life on earth. In this sense, God is carnal, God is earthen, God is flesh.

In this essay I take up the question of Christianity's earthen identity by way of a biblically inflected, nature-based retrieval of the Holy Spirit as the green face of God in the world. ${ }^{2}$ Taking my cue from the Bible's definition of the Spirit according to the four cardinal elements, I begin with an analysis of how the Spirit reveals herself in the scriptural literatures as a physical, earthly being who indwells the earth-even as the earth enfleshes the Spirit. ${ }^{3}$ To make this point I develop a case-study of the Crum Creek (a local watershed near my home and workplace) as a Spirit-filled (albeit degraded) sacred place because it continues to function as a vital if threatened habitat for a wide variety of plant and animal species. But if it is the case that the earth embodies the Spirit's power and love for all things, then whenever this fragile, green planet-God's earthen body, as it were-undergoes deep environmental injury and waste, it follows that God in Godself also experiences pain and deprivation. ${ }^{4}$ Since God and the earth, Spirit and nature, share a common reality, 
the loss and degradation of the earth means loss and degradation for God as well.

This model of sacred-land theology raises two troubling criticisms that I will seek to address here. On the one hand, some environmental deconstructionists question appeals to nature per se in formulations such as mine for, as they see it, betraying a crude essentialism that fails to account for the founding interpretive assumptions that shape one's experience of the natural world. On the other, some Christian ecotheologians question appeals to earth community as sacred, holy ground-the site of God's earthen presence-as surreptitiously idolatrous. My response to these criticisms will be to develop a rhetorically rich, rather than essentialist, celebration of Christianity's quasi-animist understanding of God's Spirit as both beyond all things and radically enfleshed within all things. I will conclude that it is crucial for the vitality of the planet, and the health of our own species, to reimagine theologically the mutual interrelationship of Spirit and earth. A deep-green recovery of Christianity's central teaching about the unity of God and nature is essential to awakening both a sense of kinship between our kind and otherkind and the concomitant desire for the well-being of the land that is our common home and destiny. Unless we can experience again a spiritually charged sense of kinship with the more-than-human world, I fear that the prospects of saving our planet, and thereby saving ourselves, are dim and fleeting at best. ${ }^{5}$

\section{LANDSCAPES OF THE SPIRIT: THE CONTEST BETWEEN SPIRIT} AND FLESH

While I maintain that Christianity's primordial identity is fundamentally nature-centered and body-loving, it is no secret that this thesis has historically been at odds with a residual Platonist tendency within Christian theology to devalue, even demonize, the realities of body and world. Many of the church's most influential early thinkers were enamored with Plato's controlling philosophical metaphors of the body as the "prison house" or the "tomb" of the soul. The fulfillment of human existence, according to Plato, is to release oneself-one's soul-from bondage to involuntary, bodily appetites in order to cultivate a life in harmony with one's spiritual, intellectual nature. ${ }^{6}$ Origen, the third-century Christian Platonist, literally interpreted Jesus' blessing regarding those who 'have 
made themselves eunuchs for the sake of the kingdom of heaven" and at age twenty had himself castrated. ${ }^{7}$ Consistent with the theology of Pseudo-Titus, Origen became a virgin for Christ who was no longer dominated by his sexual and physical drives - he became a perfect vessel for the display of the power of the Holy Spirit over bodily temptations. ${ }^{8}$

This long tradition of hierarchical and antagonistic division between spirit and matter continues into our own time-an era, often in the name of religion, marked by deep anxiety about and hostility toward human sexuality, the body, and the natural world. And yet, the biblical descriptions of the Holy Spirit do not square with this oppositional understanding of spirit and flesh. Granted, the term "Spirit" does conjure the image of a ghostly, shadowy nonentity in both the popular and high thinking of the Christian West. In her earlier work, for example, Sallie McFague argued that the model of God as Spirit is not retrievable in an ecological age. She criticized traditional descriptions of the Spirit as ethereal and vacant, and concluded that Spirit-language is an inadequate resource for the task of earth-healing because such language is "amorphous, vague, and colorless."9 Later, however, McFague performed the very retrieval of pneumatology she had earlier claimed to be impossible: a revisioning of God as Spirit in order to thematize the immanent and dynamic presence of the divine life within all creation. ${ }^{10}$ "[T] divine wind that 'swept over the face of the waters' prior to creation, the life-giving breath given to all creatures, and the dynamic movement that creates, recreates, and transcreates throughout the universe. Spirit, as wind, breath, life is the most basic and most inclusive way to express centered embodiment." 11

McFague's recovery of scriptural Spirit-breath language underscores how the biblical texts stand as a stunning countertestimony to the conventional mind-set that opposes Spirit and flesh. Indeed, the Bible is awash with rich imagery of the Spirit borrowed directly from the natural world. The four traditional elements of natural, embodied life-earth, air, water, and fire-are constitutive of the Spirit's biblical reality as an enfleshed being who ministers to the whole creation God has made for the refreshment and joy of all beings. In the Bible, the Spirit is not a wraithlike entity separated from matter, but a living being, like all other created things, made up of the four cardinal substances that compose the physical universe. $^{12}$ 
Earth, Air, Water, Fire

Numerous biblical passages attest to the foundational role of the four elements regarding the earthen identity of the Spirit.

(I) As earth the Spirit is both the divine dove, with an olive branch in its mouth, that brings peace and renewal to a broken and divided world (Gen. 8:Ir; Matt. 3:I6; John I:32), and a fruit-bearer, such as a tree or vine, that yields the virtues of love, joy, and peace in the life of the disciple (Gal. 5:15-26). Pictured as a bird on the wing or a flowering tree, the Spirit is a living being who shares a common physical reality with all other beings. Far from being the "immaterial substance" defined by the canonical theological lexicon, the Spirit is imagined in the Bible as a material, earthen life-form who mediates God's power to other earth creatures through her physical presence.

(2) As air the Spirit is both the vivifying breath that animates all living things (Gen. I:2; Ps. 104:29-30) and the prophetic wind that brings salvation and new life to those it indwells (Judg. 6:34; John 3:6-8; Acts 2:I-4). The nouns for Spirit in the biblical texts-ruach in Hebrew and pneuma in Greek-mean "breath" or "air" or "wind." Literally, the Spirit is pneumatic, a powerful, air-driven reality analogous to a pneumatic drill or pump. The Spirit is God's all-encompassing, aerial presence in the lifegiving atmosphere that envelopes and sustains the whole earth; as such, the Spirit escapes the horizon of human activity and cannot be contained by human constraints. The Spirit is divine wind, the breath of God, that blows where she wills (John 3:8) - driven by her own elemental power and independent from human attempts to control her-refreshing and renewing all broken members of the created order.

(3) As the living water the Spirit quickens and refreshes all who drink from her eternal springs (John 3:I-I5, 4:I4, 7:37-38). As physical and spiritual sustenance, the Spirit is the liquid God who imbues all life-sustaining bodily fluids-blood, mucus, milk, sweat, urine-with flowing divine presence and power. Moreover, the Water God flows and circulates within the soaking rains, thermal springs, ancient headwaters, swampy wetlands, and teeming oceans that constitute the hydrospheric earth we all inhabit. The Spirit as water makes possible the wonderful juiciness and succulence of life as we experience God's presence on a liquid planet sustained by nurturing flow patterns. 
(4) Finally, as fire the Spirit is the bright flame that alternately judges evildoers and ignites the prophetic mission of the early church (Matt. 3:II-I2; Acts 2:I-4). Fire is an expression of God's austere power; on one level, it is biblically viewed as the element God uses to castigate human error. But it is also the symbol of God's unifying presence in the fledgling Christian community where the divine pneuma - the rushing, whooshing wind of God-is said to have filled the early church as its members became filled with the Spirit, symbolized by "tongues of fire [that were] distributed and resting on each one" of the early church members (Acts 2:3). As well, like the other natural elements, fire is necessary for the maintenance of planetary life: as solar power, it provides warmth and makes food-preparation possible; as wildfire in forested and rural areas, fire revivifies long-dormant seed cultures necessary for biodiverse ecosystems. The burning God makes alive the elements of the lifeweb essential for the sustenance of our gifted ecosystem.

God as Spirit is biblically defined according to the tropes of earth, wind, water, and fire. In these scriptural texts the Spirit is figured as a potency in nature who engenders life and healing throughout the biotic order. The earth's bodies of water, communities of plants and animals, and eruptions of fire and wind are not only symbols of the Spirit-as important as this nature symbolism is-but share in the Spirit's very nature as the Spirit is continually enfleshed and embodied through natural landscapes and biological populations. Neither ghostly nor bodiless, the Spirit reveals herself in the biblical literatures as an earthly life-form who labors to create and sustain humankind and otherkind in solidarity with one another.

Running rivers, prairie fires, coral reefs, schools of blue whales, equatorial forests - the Spirit both shares the same nature of other life-forms and is the animating force that enlivens all members of the life-web. As the breath of life who moves over the face of the deep in Genesis, the circling dove in the Gospels who seals Jesus' baptism, and the Pentecostal tongues of fire in Acts, the Spirit does not exist apart from natural phenomena as a separate, heavenly reality externally related to the created order. Rather, all of nature in its fullness and variety is the realization of the Spirit's work in the world. The Spirit is an earthen reality-God's power in land, water, and sky that makes all things live and grow toward their natural ends. God is living in the ground, swimming through the 
oceans, circulating in the atmosphere; God is always afoot and underfoot as the quickening life-force who yearns to bring all denizens of this sacred earth into fruition and well-being.

\section{A SACRED PLACE: SOJOURNING IN THE CRUM CREEK}

I turn now to an analysis of the Crum Creek watershed, at the edge of the Swarthmore College campus near my home and the place where I work, as a case-study to illustrate my overall thesis concerning green pneumatology. Crum Creek winds through a thirty-eight-square-mile area of land that sits on the western edge of suburban Philadelphia. This area is a network of streams, wetlands, and aquifers that supplies two hundred thousand households and businesses with drinking water as well as being a discharge site for wastewater effluent and a natural floodway for storm water events. The watershed is a scenic retreat for persons in the Philadelphia area who need a place of refuge from the strains and stresses of urban life. And it is an important habitat for many native plants and animals.

A variety of species of wildlife relies on the Crum Creek watershed for food and habitat in which to raise their young. Scarlet tanagers migrate from Colombia and Bolivia to lay their eggs in the old-growth forests surrounding the creek area. Spotted and red-backed salamanders are two of the twelve or so species of amphibians that live within and along the banks of the creek and its tributaries. Monarch butterflies migrate from Mexico to the open meadows of the watershed area, where they roost to feed on milkweed plants and lay their eggs. Ancient southern red oaks survive in a section of the Crum Woods near the Swarthmore campus in an aboriginal forest relatively undisturbed by white settlement. American eels migrate downstream through the creek every fall to lay their eggs in the Sargasso Sea near Bermuda; in turn, their offspring then swim upstream to mature in the same creek area where their parents began their own journeys out to sea. And showy, large-flowered trillium wildflowers fade from white to pink each year in the deep, rich woods of the watershed. ${ }^{13}$

The Crum Creek near the Swarthmore campus is my favorite site for passive recreation and easy walking meditation. Living in a world awash in parking lots and strip malls, I find it healing and restorative to be able to take refuge in the dark quiet of the woods. Henry David Thoreau 
writes about the art of getting lost, the vertiginous pleasure of abandoning oneself to a natural place without the artificial supports of urban maps and street signs. "Not until we are lost do we begin to understand ourselves," says Thoreau. ${ }^{14}$ Today many of us travel with cell phones and global positioning devices so that no one need go missing and become confused about where they are. But in taming wild places and making them the quantifiable objects of our measurement and control, we have done harm to our basic humanity, our basic animal nature. We are animal beings at our core. Our need for sleep, hunger for food, drive for companionship, and desire for sex are telling signs of our carnal natures. To be sure, we are animals that are self-aware and self-conscious, animals whose conscience can burn with shame and guilt, animals who create art, engage in science, and produce grand mythologies that map the cosmos and set forth the roles each of us should play. But we are animals all the same.

To be divorced from our fleshly, bodily natures - not to see and hear the mad rush of a swollen river in the early spring or the smell of moist leaf litter in the autumn in the woods around us-is to be cut off from the vital tapsprings that make us who we are. We live and work in fixedglass, temperature-controlled buildings sealed off from the natural world; we transport ourselves in fossil-fuel machines that require ever-widening incursions into undisturbed habitats; we eat processed food that has been genetically manipulated, irradiated, and then sealed in airtight packaging in order to preserve its interminable shelf life. We have replaced lives lived in sustainable harmony with the rhythms and vitalities of the natural order with soul-deadening, consumption-intensive lifestyles that leave us emotionally depleted and spiritually empty. We need untamed places to return us to our animal identities, and I am deeply grateful for the role the Crum Woods plays in my own return to the wildness within me.

The Crum Creek is a celebration of the natural amity that characterizes the human and the more-than-human spheres of existence. It is a place of scenic beauty, sensual delight, and spiritual sustenance. Like the ancient groundwater aquifers in the woods that are recharged by winter snows and spring rains, the depths of my own inner life are recharged by regular sojourns along the forested banks of the streams and tributaries that make up the watershed. 
But in spite of its natural beauty and seeming health, all is not well with the Crum Creek. There are many threats to the biodiversity and well-being of the creek area. Overall development pressures pose the largest perils to the integrity of the watershed. In the upper portion of the creek area, housing construction, shopping centers, office parks, and parking lots have fragmented natural habitats and increased the amount of paved areas, leading to storm water runoff problems. In the lower portion of the creek near Swarthmore College, continued institutional development by the college along the edges of the watershed has created the same sorts of problems. Ironically, while Swarthmore College has been a relatively benign caretaker of the woods near its campus for many generations, in recent years the college's growth pattern has made it a threat to the preservation of species and habitat in the lower Crum Creek. This troubling growth pattern entails cutting down edges of the forest preserve to open up space for college facilities. Since the rg6os new townhouses for faculty, expanded student dormitories, additions to existing academic buildings, new access roads, and construction of surface parking lots have shrunk the perimeter of the forest. These past and possible future uses of forest near the college campus raise troubling questions about the long-term health of the Crum Creek watershed.

\section{The Crum Creek as the Wounded Sacred}

Degraded but still robust, wounded but still alive-the Crum Creek watershed is an impaired wildlife area that continues to supply water, food, and other basic elements to the many communities, human and nonhuman, that flourish alongside and within its banks and streams. Though the Crum Creek suffers regular abuse, to me it is a sacred place, a place where I am nourished and affirmed in my religious quest, a place where I find God.

But does it really make sense to say that the Crum Creek is a sacred place? Today our common discourse has expanded to make almost anything we do and believe in sacred. Special periods spent with family is "sacred" time. The important responsibilities assumed by law enforcement officers or child-care workers is a "sacred" trust. And almost anyplace one might venture-from a graveyard to a churchyard, from a memorable site in one's childhood to a battlefield or even a football stadium — can be a candidate for a sacred place. But if anything or any 
place can be sacred, then what is not sacred? If the term is so elastic as to include virtually any activity or place we might imagine, then does the term any longer carry any significance?

I grant that to honor the Crum watershed as a sacred place appears, at first glance, to continue to expand the use of this term to include locales that might not obviously appear to be sacred sites. The Crum Creek is not a built religious structure like a church or a temple. It is not a timehonored legacy site such as a war memorial or historic battleground. It is not even a widely recognized natural place of extraordinary beauty and grandeur, such as the Grand Canyon or Yellowstone National Park. Nevertheless, the Crum watershed is a living system that supports an astonishing wealth of native wildlife, and insofar as it continues to function as a vital habitat for a variety of species and their young, it is a "sacred" place.

Health and vitality are the highest ideals that make life on earth possible and worth living. The preservation of species-richness, which directly supports the stability and productivity of diverse biological communities, is the supreme value that nurtures human and nonhuman flourishing on our fragile planet. A place where God especially dwells, a place that is "sacred," is a place where ecosystem diversity is protected so that the miracle of self-regulating species-development is allowed to thrive. God as Spirit inhabits the biotic support systems on which all life depends, invigorating these systems with divine energy and compassion. The Crum Creek is not a pristine watershed; it will not win any virgin forest or clean water awards. But it is a site for the landed sacred, a place where God is alive and present because it is a small, and increasingly rare, patch of earth and river in harmony with itself that supports the well-being of its living inhabitants. ${ }^{15}$

Wherever there are places left on earth where natural ecosystems are in balance with their surroundings, there is God's presence. God is the giver of life, the sustainer of all that is good, the benevolent power in the universe who ensures the health and vitality of all living things. The Crum Creek watershed-battered and degraded though it may becontinues to function as a balanced and self-sustaining network of lifegiving habitat for plant, animal, and human well-being. The life-giving role the Crum Creek performs is divine in the truest sense of the word because it describes precisely the role God performs in and through the 
earth: to give life, to make all beings come into fruition, to sustain the zest and vigor of creation. In this sense, the Crum Creek and God are one because they are both sources of life and health for earthen beings. To say, then, that the Crum watershed is a sacred place does not debase the meaning of the word "sacred" by designating just any such place as sacred or religious based on personal whim or fancy. On the contrary, to celebrate the Crum Woods as a sacred place is to drop to one's knees on the ground, and extend one's arms to the sky, in order to honor this place of God's indwelling as one of the remaining life-giving habitats on our planet that make our existence, indeed the existence of all of us, possible.

The Crum Creek is sacred, indeed, but the Crum Creek survives today as the wounded sacred. Envisioning Spirit and the Crum habitat as one opposes the classical theological idea of God as unchangeable and apathetic in the face of the suffering and turmoil within creation that God birthed into existence. God's Spirit is not a distant abstraction but a living being who subsists in and through the natural world. Because God as Earth Spirit lives in the ground and circulates in water and wind, God suffers deeply the loss and abuse of our biological heritage through our continued assaults on our planet home. God as Spirit is pained by ongoing ecosqualor; God as Spirit undergoes deprivation and trauma through the stripping away of earth's bounty. As the earth heats up and melting polar ice fields flood shore communities and indigenous habitats, God suffers; as global economic imbalance imperils family stability and intensifies the quest for arable land in native forests, God suffers; as coral reefs bleach into decay and whole ecosystems of fish and marine life die off, God suffers; and as stream quality and wildlife habitats endure further degradation in the Crum watershed, God suffers. When we plunder and lay waste to the earth, the Spirit suffers as God's presence on a planet that is enduring the loss of natural resources and cascading speciesextinction. The Spirit is the injured sacred, the enfleshed reality of the divine life who grieves over what may become a lost planet, at least for human habitation and that of countless other species. As the Spirit is the suffering God, so also is the body, so to speak, of the Spirit's worldly presence, the earth itself, the wounded sacred. Together in a common passion and common destiny, the Spirit of God and an earth scarred by human greed body forth the wounded sacred in our time. 
In the green Spirit perspective suggested here, God's vulnerability as a fleshly being and damage to the Crum watershed are one and the same reality. Even today, the Crum Woods are one of many surviving networks of life-giving habitat that manifest God's bounty and compassion in the earth. But the Crum Creek also displays the Spirit of God's deep and abiding suffering in our present time as well. As toxins from ruptured sewer lines and storm water leech into the creek, as the edges of the forest are cut down to make way for more suburban sprawl and commercial and institutional growth, God's Spirit experiences the loss and depredation of this delicate watershed in the depths of Godself. God is harmed by what we do. God is injured by the ways in which we despoil the natural systems that have supported life in many bioregions, including the Crum Woods, for tens of thousands of years. Spirit in love with the land-God in friendship with this small strip of Pennsylvania greenway-are co-determined, fellow sufferers in a unified effort to bring sustainable well-being to earth community. The Crum Creek is a small but important member of the Spirit's earthen body; as is all of creation, this forest fragment is part of the body of God's material presence. When the Crum Creek suffers, God suffers as well, reminding all of us to travel lightly on the earth as we participate in the evolution of particular ecosystems, including the evolution of this particular watershed.

\section{THE CHALLENGE OF DECONSTRUCTION: IS NATURE REAL?}

If nature is the primary focus of an earthen theological perspective, then what do we mean by the term "nature" when we valorize it in this way? Postmodern deconstruction questions assumptions about the seeming self-evidential character of landed reality and thereby challenges green spirituality to re-examine its basic identity and suppositions. The postmodern project seeks to show how knowledge about the world is generated through language and culture. If the task of an earlier modernism was to uncover the nature of reality as stable and ordered, the task of postmodernism is to destabilize or deconstruct notions of so-called reality by laying bare the ways human understanding of the world is always already a product of culturally embedded interpretive activity. ${ }^{16}$ Postmodernism's challenge to religious ecology, then, is to question whether green theology's "turn to nature" betrays a crude understanding of the 
natural world as a self-evident set of facts, when the meaning and significance of the purported facts that make up reality are actually imposed upon the world based on prized cultural assumptions. There is no empirically obvious "raw" nature that tells us what reality is really like; rather, we import into the natural world socially mediated presumptions about our proper role in nature in relation to the wider world around us. ${ }^{17}$ Weighing in on the postmodern constructivist side of the discussion is William Cronon, a history professor at the University of Wisconsin, and a group of interdisciplinary scholars whose 1994 seminar with Cronon at the University of California at Irvine explored the theme "Reinventing Nature." 18 Cronon and his colleagues argue that "nature" is a term loaded with cultural baggage. Nature is not a fixed reality but a valueladen concept whose meanings undergo dramatic shifts over time. Ironically, there is little if anything that is natural about nature because both the term "nature" and the reality to which it corresponds have been ineluctably shaped by human desires and imaginings. Cronon writes:

Popular concern about the environment often implicitly appeals to a kind of naive realism for its intellectual foundation, more or less assuming that we can pretty easily recognize nature when we see it and thereby make uncomplicated choices between natural things, which are good, and unnatural things, which are bad. Much of the moral authority that has made environmentalism so compelling as a popular movement flows from its appeal to nature as a stable external source of nonhuman values against which human actions can be judged without much ambiguity. If it now turns out that the nature to which we appeal as the source of our own values has in fact been contaminated or even invented by those values, this would seem to have serious implications for the moral and political authority people ascribe to their own environmental concerns. ${ }^{19}$

Cronon's point is that ecoactivists' unexamined assumptions about the nature of nature-which they assume to be a self-revealing order of being imbued with inherent worth—mask the highly imaginative constructions of nature crafted by human cultures. The ecoactivists' essentializing orientation toward nature is generally taken for granted. Of course, this orientation is pragmatically useful as it serves as the basis for the moral 
exhortations by environmentalists to take up the plight of nature and fight against the destruction of our planet home. Thus the understandable fear for some environmentalists is that by moving away from regarding nature as a self-evidential good to redefining nature as a cultural construction, the grounds for action in defense of the earth will be effectively undermined.

Not only do Cronon's critics regard his constructivism, therefore, as undercutting green activism, but they also regard his position as a stalking horse for pro-development forces opposed to systemic environmental protection. By examining nature within the confines of cultural relativism and projectionism, Cronon provides intellectual backing for conservative policymakers and developers who maintain that nature is not an absolute good to be defended at all costs but, instead, a resource to be used to serve the ideal of human flourishing. Nature is morally ambiguous, since "nature" is not "naturally" good or bad. Cronon's critics argue that if you say nature is not an intrinsic, self-evident good that cries out for our protection, you are then giving tacit permission to antienvironmental forces to exploit the natural world in whatever way they deem necessary in order to serve their commercial interests.

The argument of Cronon's critics is that (a) once nature is deconstructed as a project of discourse with (b) no inherent capacity for providing criteria to adjudicate which projections are better than others, then it follows that (c) nature can be used and abused to serve selfish human ends since its true essence is always filtered through the lens of imaginal activity. If nature is not a fixed, objective fact that tells us what to do, then it becomes a candidate for exploitation and depredation. This is the main point environmentalists make in opposition to Cronon. In a trenchant criticism of Cronon and his ilk, deep ecologist George Sessions writes that "for most postmodernists, there is no standpoint beyond human cultures ... there is no objective truth-all theories and statements (even by scientists) reflect only the interests of power elites; and that since Nature is a human construction, humans can 'reinvent Nature' . . . in any way that suits our immediate interests and desires." ${ }^{\prime 20}$ Earth First! and Wilderness Society cofounder Dave Foreman writes similarly that "the irony of Cronon is that he is the kind of intellectual the antiwilderness populists decry in their red-faced anti-intellectualism, yet he 
gives these people arguments to use against wilderness (and they are using Cronon's arguments)." 21

But it is important to note Cronon's claim that his attention to the value-laden character of nature discourse is intended to strengthen, not undermine, environmental thinking and action. Cronon believes that the commitment to earth healing will become more honest and effective when environmentalists learn to become more nuanced and selfreflective in their use of the term "nature" in their moral language and ethical engagements. Though unadulterated nature is beyond our reach, Cronon's hope is that by examining the rhetorical constructions of nature within human cultures, environmentalists will become more sensitive to the various uses and abuses to which the idea of nature has been put. With this new sensitivity in place, the fight for nature can proceed with renewed vigor as it attends to the terminological and political shades of meaning employed on behalf of - and against - the integrity of the natural world.

In my mind, while Cronon and the Irvine group are at pains to argue that the concept "nature" is a human idea, they are not thoroughgoing idealists. Their opposition to naïve realism - the commonsense notion that the external world is fully knowable apart from cultural mediationdoes not entail subscription to the extreme antirealist or idealist position that the material world either does not exist or is fundamentally unknowable. Cronon and his supporters do not argue that physical objects and places like rocks and trees and wetlands have no reality apart from our perception of these objects and places; rather, their point is that the cultural meanings we attach to these things are largely a human affair and cannot be divorced from any supposed inherent qualities these objects and places have apart from our interpretation of them. In spite of the dismissals by his critics, Cronon for his part labors to make clear his desire to hold in tension the constructivist thesis that the concept of nature is a cultural invention with the realist notion that the actual material world exists independently of being perceived. In this sense, Cronon is neither, philosophically speaking, an extreme idealist nor, politically speaking, opposed to preserving the integrity of the natural world. He says:

Asserting that "nature" is an idea is far from saying that it is only an idea, that there is no concrete referent out there in the world for 
the many human meanings we attach to the word "nature." . . . Yosemite is a real place in nature-but its venerated status as a sacred landscape and national symbol is very much a human invention. The objects one can buy in stores like The Nature Company certainly exist in nature-but that does not begin to explain how they came to inhabit some of the most upscale malls in modern America. ${ }^{22}$

In green theology's encounter with deconstruction, deconstruction pulls back the veil of our most prized notions - notions such as "nature" or "the world"-and show us that such notions betray our attachments to often hidden assumptions about what constitutes our picture of reality. Whenever theorists (including religious theorists) claim to delineate "how things really are," they are, in fact, representing their own presuppositions and convictions as much as they are describing the so-called real world. There is nothing wrong with this sort of value-laden mode of analysis as long as scientists, theologians, activists, and others recognize how their own personal worldviews and beliefs are implicated in the accounts they give of the realities they describe. In this vein, nature is not natural: nature is not raw and ready to be discovered by the individual observer because nature is always being constructed according to the socially mediated, partisan convictions of the observer in question.

Green Spirit theology finds this constructionist model of knowing to be a healthy tonic in its attempt to articulate an earth-friendly religious vision. Constructionism helps to keep theology honest in its reminder that all claims to reality are partial and reformable. Now fully aware that the meaning of the natural world is generated through cultural assumptions, green theology enters the public fray clear-headed about its own founding assumptions and clear-sighted in its distinctive vision of an interdependent world charged with the healing power of the Spirit in all things. Purified of its essentializing tendencies through its hygienic encounters with deconstruction, green theology takes its place in the public square aware of its need to make a strong rhetorical case regarding the liberatory truth of God's earthen love for all members of the biosphere and human beings' concomitant responsibility to care for creation. It is not obvious that nature is the abode of Spirit and that compassionate, 
sustainable relations with earth community are incumbent upon all persons, religious or not. Nature per se does not tell us anything; its meanings are created on the basis of our kinship with its regular flow patterns. But when we attune ourselves to these daily rhythms, then we can engage in the constructive task of articulating to others a vision of a renewed earth where all of God's creatures live in harmony with their surroundings.

THE CHARGE OF IDOLATRY: COBB'S CRITIQUE OF SACREDLAND THEOLOGY

In traditional Christian thought only God is sacred. God alone is supremely absolute and sovereign over the whole created order. All other beings, while valuable as products of God's creative love and bearers of God's image, only have value and worth relative to God. The dominance of this model is entirely understandable given the important theological images in the Bible and Christian liturgy that focus on God as Lord, King, Sovereign, Ruler, Monarch, and Judge. From a monarchical vantage point the biblical message is clear: God is sovereign, just, and good, and all of God's creaturely subjects - plants and trees, human beings and other beings, ocean, land, and sky — have value and goodness only derivatively in relation to the supreme life source of God in Godself.

John B. Cobb Jr., who, along with Joseph A. Sittler, is arguably the father of Christian environmental theology, has consistently rejected this feudal view of God and the world. His 1972 book Is it Too Late? A Theology of Ecology, written in the wake of first-wave environmental awareness during the social justice movements of the r96os, is a searching indictment, on the one hand, of how Christian kingly theology has paved the way for ecological destruction and, on the other, a visionary proposal for an earth-friendly theological agenda. ${ }^{23}$ This pathbreaking book was followed, along with other works written by Cobb, by For the Common Good: Redirecting the Economy toward Community, the Environment, and a Sustainable Future, coauthored with Herman E. Daly, which further refines Cobb's ecological vision in dialogue with process theology, natural science, and holistic economics. ${ }^{24}$ Cobb's process theology is an exercise in panentheism: God and the world are internally related realities brought together in a dynamic process of mutual transformation. ${ }^{25}$ Cobb's interdependent model of the God-world relationship is the 
grounds of his criticism of historic Christianity's myopic focus on the salvation of human beings to the exclusion of concern for the well-being of nonhuman plant and animal communities. This anthropocentric bias has blinded Christianity to the degradation of the biosphere and the suffering of individual creatures; a new vision of Christianity in harmony with nature is the demand of our time. Cobb's move, then, to a thoroughgoing green Christianity predicated on ascribing sacred value to earth community would seem to be the natural trajectory of his thought. And in certain important respects, Cobb does share basic assumptions with this orientation. All beings, including human beings, are radically and mutually interdependent on natural systems for their well-being: for human beings to destroy wantonly plant and animal life is to threaten and diminish the life quality of all of us, human and nonhuman alike.

But in spite of these core areas of agreement, Cobb also carefully distinguishes his project from that of the religious ecology suggested here. In particular, Cobb, while investing nature with spiritual power and sacramental meaning, disagrees with the tendency in nature-based religion to honor the natural world as sacred in itself. While God is in the world and benevolent toward creation, God alone is sacred. It is a dangerous misnomer, even idolatrous, to confuse the Creator and the creation and to venerate the earth as sacred along with God. In a word, God alone is holy. Cobb writes:

Nevertheless, [the sacredness of all creatures] language is, from a historic Protestant perspective, dangerously misleading. Speaking rigorously, the line between the sacred and the profane is better drawn between God and creatures. To place any creatures on the sacred side of the line is to be in danger of idolatry. For many Protestants, including process theologians, the right way to speak is incarnational, immanental, or sacramental. God is present in the world - in every creature. But no creature is divine. Every creature has intrinsic value, but to call it sacred is in danger of attributing to it absolute value. That is wrong. ${ }^{26}$

Cobb's case against sacred-land theology is twofold. His first objection is theological: such theology wrongly blurs the line of distinction needed to separate beings of relative value from the divine being itself, the bearer 
of absolute value. The specter of idolatry haunts Cobb's writings about the environment. Unless the borderland that divides Creator and creation is carefully policed, there is the danger that the value of a sacralized earth will be purchased at the price of denying the transcendence of God. Cobb is not simply speaking about the generic Protestant concern with the threat of idolatry outside of process thought; rather, he makes clear in the above quote and elsewhere that process theology shares with its Protestant conversation-partners the anxiety about idolatry in omnisacred earth theologies. Idolatry for Cobb is the confusion of realms of reality that need to be kept apart; thus his theology operates within a binary, either-or logical field: one worships either God or nature but not both. Since Christianity, in Cobb's perspective, is not an animist religion that invests the natural world with sacred, absolute value, one should worship God alone as sacred. While nature is charged with God's presence, according to Cobb, it does not follow that nature itself is a divine reality alongside or on a par with God and thereby an object worthy of our devotion and worship. To call the created order sacred, therefore, is dangerous and idolatrous: it is to run the risk of deifying and revering the earth as equal in worth and value to God. To do this is to displace God's unique role as humankind's proper object of worship and center of absolute, transcendent value.

Cobb's second objection to deep green Christianity is practical: unless one can refer to a being of absolute value, judgments of relative value are impossible to make. If all beings_everything from megafauna, such as human beings and blue whales, to microflora, such as mold spores and green algae-are sacred, if everything is equal in value and worth, then on what basis can decisions be made about what should be saved and protected and what can be used and destroyed? Without some hierarchical system that grades the relative value of different life-forms, there is no coherent foundation on which to base preservation of species, resource-allocations, food production, biomedical research, and so forth. Cobb writes that one "cannot give up the affirmation of gradations of value. All creatures have intrinsic value, but some have greater intrinsic value than others. That is to say, the inner life of some creatures is more complex, deeper, and richer than that of others." 27 Or, as he says at another point, "We believe there is more intrinsic value in a human being than in a mosquito or a virus." 28 For Cobb, God alone is sacred and 
the highest expression of absolute value; after God, humans, as beings of complex rationality and rich experience, are next in value in this ordering hierarchy; after humans, other communities of animals and plants are graded according to the depths of their cognitive functions and range of feelings and abilities. Without this sort of pecking order, moral decision making is impossible. For Cobb, extreme green spirituality is wellmeaning but wrongheaded. By affirming the sacredness of all creation, land-based theology plunges us into a night in which all things are black and there is no way to distinguish between which use patterns are healthy and sustainable and which are not. ${ }^{29}$

An alternative to Cobb's axiological hierarchy is suggested by renewed appreciation of the energy-exchange and feeding patterns that characterize diverse biological communities, a point emphasized in the previous section on the Crum Woods. In this model, supreme value is inherent in the vitality of the food-web vis-à-vis God's Spirit; it is characteristic of the natural life process of biocommunal eating and being eaten as that process is energized by divine power. Supreme value is not an attribute of one reality (God) over and against another reality (the earth) because both realities are one (dialectically understood). By the same token, distinctions regarding relative value and worth are not made by first privileging human beings as bearers of more intrinsic value than other beings. The task of Christian earth healing would be to ensure, therefore, the health and dynamism of the life cycle rather than protect the interests of added-value beings (such as human beings) whose inner life is supposedly more richer and complex than other beings. Thus deep green spirituality is able to make highly nuanced and sophisticated practical judgments about use and value, but it does so in biocentric rather than anthropocentric terms. Such judgments are made not in relation to the putative higher value of human beings but on the basis of maintaining healthy predator-prey relationships within the food-web - that is, in reference to how energy is obtained and transmitted through a series of exploitative and mutualistic relationships among different and interconnected living things. Aldo Leopold, the early-twentieth-century Wisconsin conservationist and forest advocate, alternately refers to this flow of energy according to highly organized systems of biotic relationships as the "food chain," the "energy cycle," or the "land pyramid": 
Plants absorb energy from the sun. This energy flows through a circuit called the biota, which may be represented by a pyramid consisting of layers. The bottom layer is the soil. A plant layer rests on the soil, an insect layer on the plants, a bird and rodent layer on the insects, and so on up through various animal groups to the apex layer, which consists of the larger carnivores.

The lines of dependency for food and other services are called food chains. Thus soil-oak-deer-Indian is a chain that has now been largely converted to soil-corn-cow-farmer. Each species, including ourselves, is a link in many chains. The deer eats a hundred plants other than oak, and the cow a hundred plants other than corn. Both, then, are links in a hundred chains. The pyramid is a tangle of chains so complex as to seem disorderly, yet the stability of the system proves it to be a highly organized structure. Its functioning depends on the cooperation and competition of its diverse parts. ${ }^{30}$

Green spirituality can learn a lot from conservation biology about the crucial importance of food-webs for ensuring the future of the planet. Scientifically speaking, in the natural order, everyone is food for everyone else. Human beings, for example, both eat and then are eaten by fungi, bacteria, and often insects and other anthropods as well. Everyone is predator and prey in relation to other living things. All of us, from the smallest bug to the largest carnivore, rely on this complicated flow mechanism for our daily bread. Moreover, all beings play an equal and vital role in maintaining the integrity of the energy cycle; no one member of this integrated plant and animal community is any more important in sustaining the cycle than any other member. Theologically speaking, then, judgments about value should be based not on human needs but on keeping open the living channels of energy that make life possible. This is the point Leopold makes in his general maxim for a land ethic: "A thing is right when it tends to preserve the integrity, stability, and beauty of the biotic community. It is wrong when it tends otherwise." ${ }^{31}$ Value accrues to the health and vitality of the food-web; it is not a property of particular organisms - in other words, more complex creatures do not get more intrinsic value than less complex creatures.

Cobb is very articulate about the role biotic interdependence plays in the life-cycle. ${ }^{32}$ But his fear about ascribing sacredness to nature, and his 
human-centered value system, blunts a full turn toward the biocentric theology adumbrated here. His emphasis on subjective experience as the criterion for making comparative value judgments undercuts the power of the food-web model to make clear that real value inheres in the integrity and well-being of the web itself. As humans, according to this "webfirst" model of reality, we should simply see ourselves as equal citizens of the biotic order-we do not possess more value than other beings. Some critics regard this subordination of human concerns to the welfare of the whole as a type of misanthropic thinking, even a kind of ecofascism in which human interests are now located in (or subordinated to) the wider orbit of ecosystemic interests. But the point is not that human happiness is unimportant in green systems thinking but rather that, without the well-being of the whole as the paramount concern, attention to human needs and interests is not possible. To put the point bluntly, if the worldwide system of energy flow patterns collapses due to ecocatastrophe of our own making, then our discussions about whether human beings have more value than other beings will seem academic at best and, at worst, contributory to the very mind-set that gave rise to the collapse in the first place.

Cobb (and others) criticize sacred-land theology as flirting with idolatry. But the witness of Scripture and Christian tradition is to the world as the abode of divinity, the home of life-giving Spirit, God's here-andnow dwelling place where the warp and woof of everyday life is sacred. All life is sacred because the earth is a natural system, alive with God's presence, that supports the well-being of diverse ecological communities. God's gift to all beings is Earth itself: this highly complex, biologically diverse system of interlocking relationships where enfleshed existence is celebrated in all its fecundity and passion. Sacredness resides in the Godgiven capacity of native plants and animals to stock and replenish the food-web on which we all depend. Supreme value inheres in the Spiritinfused dynamism and elasticity of the energy cycle that makes our lives and the lives of other beings endlessly rich and potent with new possibilities. The Spirit is the green face of God who animates the living food chains that make possible the flow of energy and sustenance for all of us. God is not a dispassionate and distant potentate, as in classical feudal theology, who exercises dominion over the universe from some farremoved place; rather, in and through this planet that is our common home, God is earnestly working with us to heal the earth. 
And yet, as we have seen, God also suffers deeply from the agony of inhabiting a planet badly degraded and out of harmony with itself. For this reason I have said that the green Spirit who infuses all things with her benevolent presence is also the wounded Spirit who implores us, in groans too deep for words, to practice heartfelt sustainable living in harmony with the natural world around us. In a highly insightful discussion of the Spirit's relationship to nature, the apostle Paul writes that human arrogance has caused the whole creation to groan in agony as it awaits final deliverance. To update Paul's insights and correlate them with the contemporary ecocrisis, Paul's writings about the Spirit appear uncannily prescient: our hostile treatment of the earth has now plunged all of creation into deep suffering and travail. He writes: "The creation waits with eager longing. ... . [to] be set free from its bondage to decay and obtain the glorious liberty of the children of God. We know that the whole creation has been groaning in travail together until now; and not only the creation, but we ourselves, who have the first fruits of the Spirit, groan inwardly as we wait for adoption as sons, the redemption of our bodies" (Rom. 8:19-23). In the midst of the current crisis, all of creation groans under the weight of humankind's habitual ecoviolence. We feel the weight of this crisis, and we sense the Spirit alive within each of us, moaning out of pain and yearning for the renewal of a green, healthy, vibrant planet. In visceral sighs too deep for words, as Paul writes, the earthen God inwardly calls on us to care for our planetary heritage. God as Spirit agonizes over the squalor we have caused, and through her abiding earthly presence implores us to stop the violence before it is too late.

It is not blasphemous, therefore, to say that nature is sacred. It is not mistaken to find God's presence in all things. To speak in animistic terms, it is not wrong to reenvision Christianity as continuous with the worldviews of traditional peoples who bore witness to and experienced divinity everywhere-who saw and felt the Spirit alive in every rock, tree, animal, and body of water they encountered. For me it is not idolatry to enjoy the Crum Creek, degraded though it may be, as a sacred place that plays a crucial role in maintaining the health and well-being of humankind and otherkind in eastern Pennsylvania. God as Spirit is the gift of life to all creation, and where life is birthed and cared for, there God is present, and there God is to be celebrated. God is holy, and by extension all that 
God has made participates in that holiness. Thus, when we labor to protect and nurture the good creation God has made, we invest all things with inherent, supreme value as a loving extension of God's bounty and compassion.

Sacred, then, is the ground we stand on; holy is the earth where we are planted. Sacred-land theology envisions God as present in all things and the source of our attempt to develop caring relationships with other lifeforms. This perspective signals a biophilic revaluation and continuation of characteristic Christian themes. Christians speak of the embodiment of God in Jesus two thousand years ago, but now we can see the entire life-web as the incarnation of God's presence through the Spirit on a daily basis. Christians speak of the miracle of the Eucharist, in which bread and wine become Christ's flesh and blood, but now we can regard the whole earth as a living sacrament full of the divine life through the agency of the Spirit who animates and unifies all things. Christians speak of the power of the written word of God, in which God's voice can be heard by the discerning reader, but now we can view all of nature as the book of God through which one can see God's face and listen to God's speech in the laughter of a bubbling stream, the rush of an icy wind on a winter's day, the scream of a red-tailed hawk as it seizes its prey, and the silent movement of a monarch butterfly flitting from one milkweed plant to another. 